\title{
Analyses of Mineral Content and Heavy Metal of Honey Samples from South and East Region of Turkey by Using ICP-MS
}

\author{
Serap Kılıç Altun, ${ }^{1}$ Hikmet Dinç, ${ }^{2}$ Nilgün Paksoy, ${ }^{3}$ \\ Füsun Karaçal Temamoğulları, ${ }^{2}$ and Mehmet Savrunlu ${ }^{4}$ \\ ${ }^{1}$ Department of Food Hygiene, Faculty of Veterinary Medicine, Harran University, 63000 Şanliurfa, Turkey \\ ${ }^{2}$ Department of Pharmacology and Toxicology, Faculty of Veterinary Medicine, Harran University, 63000 Şanluurfa, Turkey \\ ${ }^{3}$ Department of Biochemistry, Faculty of Veterinary Medicine, Harran University, 63000 Şanluurfa, Turkey \\ ${ }^{4}$ Province Control Laboratory, Ministry of Food, Agriculture, and Livestock, 63000 Şanlıurfa, Turkey \\ Correspondence should be addressed to Serap Kılıç Altun; vetserapaltun@hotmail.com
}

Received 22 December 2016; Revised 31 March 2017; Accepted 19 April 2017; Published 11 May 2017

Academic Editor: Günther K. Bonn

Copyright (C) 2017 Serap Kılıç Altun et al. This is an open access article distributed under the Creative Commons Attribution License, which permits unrestricted use, distribution, and reproduction in any medium, provided the original work is properly cited.

\begin{abstract}
The substantial of mineral ingredients in honey may symbolize the existence of elements in the plants and soil of the vicinity wherein the honey was taken. The aim of this study was to detect the levels of 13 elements (Potassium (K), Sodium (Na), Calcium (Ca), Iron $(\mathrm{Fe})$, Zinc ( $\mathrm{Zn})$, Cadmium (Cd), Copper (Cu), Manganese (Mn), Lead (Pb), Nickel (Ni), Chromium (Cr), Aluminum (Al), and Selenium (Se)) in unifloral and multifloral honey samples from south and east regions of Turkey. Survey of 71 honey samples from seven different herbal origins, picked up from the south and east region of Turkey, was carried out to determine their mineral contents during 2015-2016. The mineral contents were analyzed by inductively coupled plasma mass spectrometry (ICP-MS). The most abundant minerals were $\mathrm{K}, \mathrm{Na}$, and $\mathrm{Ca}$ ranging within $1.18-268 \mathrm{ppm}, 0.57-13.1 \mathrm{ppm}$, and 0.77-4.5 ppm, respectively. Zn and $\mathrm{Cu}$ were the most abundant trace element while $\mathrm{Pb}, \mathrm{Cd}, \mathrm{Ni}$, and $\mathrm{Cr}$ were the lowest heavy metals in the honey samples surveyed, with regard to the concentrations of heavy metals such as $\mathrm{Zn}, \mathrm{Cu}, \mathrm{Pb}, \mathrm{Cd}, \mathrm{Ni}$, and $\mathrm{Cr}$ suggested and influence of the botanical origin of element composition. Geochemical and geographical differences are probably related to the variations of the chemical components of honey samples.
\end{abstract}

\section{Introduction}

Bees produce honey from the pollen and nectar which visit flowers, other plants, and honeydew. Honey is a kind of natural mellifluous nutrient produced from nectar and pollen grains or from secretion of living plant parts that the Apis mellifera bees collect [1]. Bees make honey to behave as a nutrient reservoir for the colony for hard times when the climate is adverse and there are no flowers [2].

The Codex Alimentarius [3] defines honey as follows: "Honey is the natural sweet substance, produced by honeybees from the nectar of plants or from secretions of living parts of plants, or excretions of plant-sucking insects on the living parts of plants, which the bees collect, transform by combining with specific substances of their own, deposit, dehydrate, store and leave in honeycombs to ripen and mature."

Honey has a superior nutritional value and it is a composition of carbohydrates such as glucose, sucrose, fructose, maltose, and other polysaccharides and oligosaccharides as well as acids, flavonoids, vitamins, minerals, waxes, aroma compounds, pollen grains, pigments, and enzymes $[4,5]$. The composition depends on the composition of nectar and honeydews [4]. Honey also contains a variety of macroand microminerals that are the minor constituents of honey present in the range $0.02-1.03 \%$. Trace elements are mainly the ash content of honey [2]. Elements are inorganic compounds which have to exist in the human body for vital activities. Elements such as $\mathrm{Se}, \mathrm{Cu}, \mathrm{Mn}, \mathrm{Fe}, \mathrm{Ni}$, and $\mathrm{Zn}$ are essential for normal metabolism [6] but above tolerance 


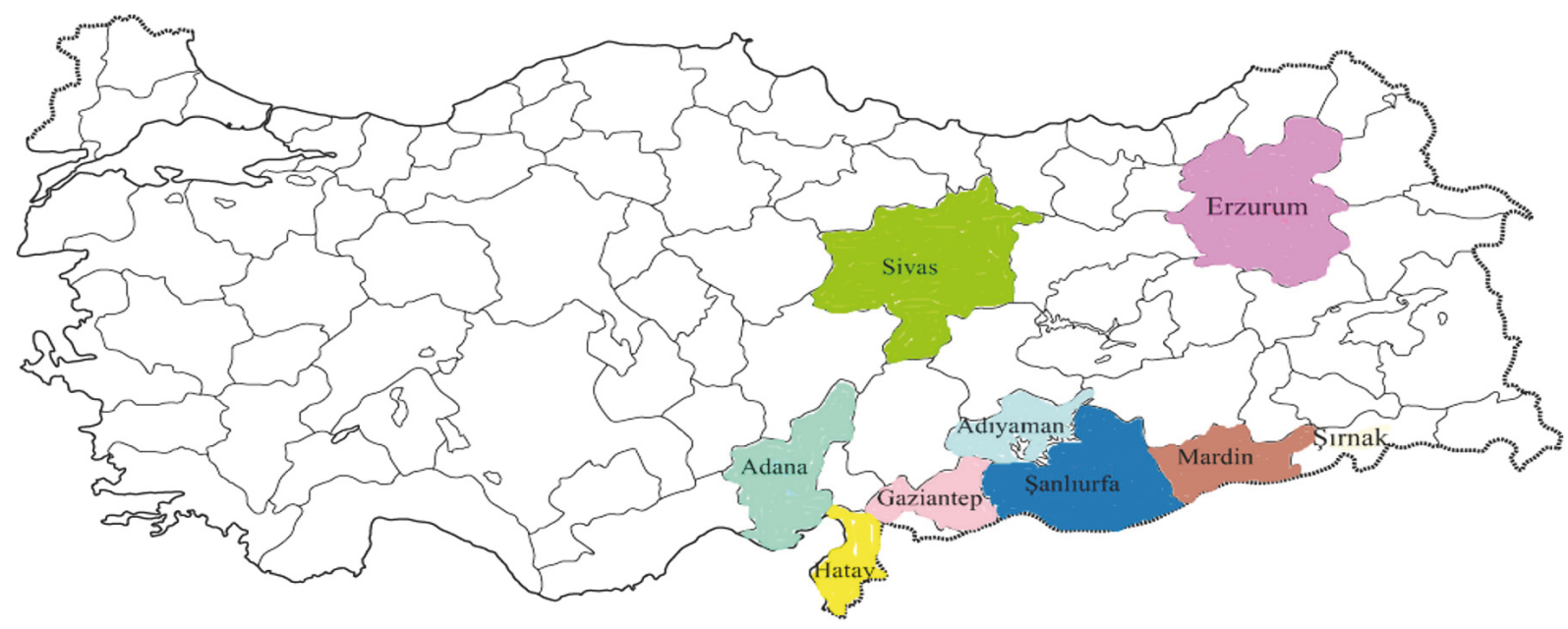

FIgURE 1: Geographical origin of honey samples.

limits they should be environmental pollutants that are hazardous for human health and trace elements such as $\mathrm{Pb}$, $\mathrm{Cd}$, and $\mathrm{Al}$ are considered as toxic and should damage the human metabolism $[6,7]$. The levels of $\mathrm{Pb}, \mathrm{Cd}, \mathrm{Ni}$, and $\mathrm{Cr}$ are unacceptable owing to their carcinogenic and cytotoxic influences [8]. The mineral and toxic metal content of honey have been used as a quality indicator [9]. Toxic metal levels of honey depend on the biological and geographical origin [10]. ICP-MS is a good technique with simultaneous determinations of elements, high sensitivity, capability, and wide linear range [11].

Honey has a great nutritional importance with high viscosity; also it has an antioxidant, bactericidal, and fungicidal effects $[12,13]$. The physical and chemical quality of honey are influenced by its geographical origin and environmental factors [14]. Honeybees are permanently exposed to the influence of industrial pollutants through the air, soil, and water [1, 12] so some researchers highlighted the possibility of honey as a biomarker [1].

Turkey is a major producer and consumer of honey with 110.000 metric ton in the world because of favorable climatic conditions. The most widely consumed honey types in Turkey are flower honey, pine honey, chestnut honey, thyme honey, astragalus honey, and citrus honey. Turkey exports honey mostly to Germany, USA, Jordan, Hungary, Iraq, Saudi Arabia, Austria, Jordon, Hungary, Belgium, Spain, and Northern Cyprus [15].

The goal of this study was to determine the levels of 13 elements ( $\mathrm{K}, \mathrm{Na}, \mathrm{Ca}, \mathrm{Cd}, \mathrm{Pb}, \mathrm{Fe}, \mathrm{Mn}, \mathrm{Cu}, \mathrm{Ni}, \mathrm{Cr}, \mathrm{Zn}, \mathrm{Al}$, and $\mathrm{Se}$ ) in unifloral and multifloral samples of honey from nine provinces that have diverse geographical and environmental characteristics, mineral composition of soil, in terms of pollution, watering, capability of being absorbed by plant, fertilizer distribution, and climatic conditions of south and east regions in Turkey.

\section{Materials and Methods}

2.1. Sample Collection. Beekeeping is widespread in Turkey: Adana, Sivas, Şanlıurfa, Erzurum, Hatay, Şırnak, Adıyaman,
TABLE 1: Botanical origin of honey samples.

\begin{tabular}{lccc}
\hline Honey type & Number of samples & Province & Total \\
\hline Unifloral & 1 & Şanlıurfa & 20 \\
Multifloral & 19 & Erzurum & 2 \\
Unifloral & 1 & Mardin & 23 \\
Multifloral & 1 & Adryaman & 1 \\
Multifloral & 23 & Sivas & 1 \\
Unifloral & 1 & Adana & 1 \\
Multifloral & 1 & Hatay & 2 \\
Unifloral & 1 & Şırnak & 1 \\
Unifloral & 1 & Gaziantep & 20 \\
Multifloral & 1 & & \\
Multifloral & 1 & & \\
Unifloral & 1 & & \\
Multifloral & 19 & &
\end{tabular}

Mardin, and Gaziantep. These province's honey production was in the 2015 year, respectively, 9763, 3327, 1502, 1473, 1176, $447,418,377$, and 142 metric ton [16] (Figure 1).

Survey of 71 honey samples from nine different herbal origins, collected from the south and east region of Turkey, was carried out to assess their mineral contents during 2015 and 2016. All collected samples (ca. $200 \mathrm{~g}$ ) were taken from the local beekeepers produced by traditional procedures with guaranteed origin and stored in closed polyethylene flasks and stored at $20-21^{\circ} \mathrm{C}$ in a lightless place until analysis (Table 1).

2.2. Reagents and Solution. Whole solutions were prepared with ultrapure water acquired by passing distilled water through a water purification system (MES MP Minipure, Turkey). All reagents were of analytical grade except otherwise stated. The standard solution of elements was obtained from standard solution Agilent Japan, Lot number: 10160YPY2. Honey samples were digested with intense hydrogen peroxide (30\% volume concentration of $\mathrm{H}_{2} \mathrm{O}_{2}$, Merck, 
TABLE 2: ICP-MS operating conditions.

\begin{tabular}{lc}
\hline RF power $(\mathrm{W})$ & 1500 \\
Plasma gas flow rate $\left(\mathrm{L} \mathrm{min}^{-1}\right)$ & 15 \\
Auxiliary gas flow rate $\left(\mathrm{L} \mathrm{min}^{-1}\right)$ & 1 \\
Carrier gas flow rate $\left(\mathrm{L} \mathrm{min}^{-1}\right)$ & 1.1 \\
Spray chamber $T\left({ }^{\circ} \mathrm{C}\right)$ & 2 \\
Sample depth $(\mathrm{mm})$ & 8.6 \\
Sample introduction flow rate $\left(\mathrm{mL} \mathrm{min}^{-1}\right)$ & 1 \\
Nebuliser pump (rps) & 0.1 \\
Extract lens $(\mathrm{V})$ & 1.5 \\
Number of replicates & 3 \\
\hline
\end{tabular}

Germany) and nitric acid (65\% volume concentration of $\mathrm{HNO}_{3}$, Merck, Germany). Spike solutions were supplied from stock solutions as a multielement solution (Agilent Japan).

2.3. Equipment and Accessories. Elemental analysis was performed on an Agilent 7500 ce with an Octopole Reaction System Inductively Coupled Plasma Mass Spectrometer with an Auto Sampler (Cetac ASX-520) and a Nebulizer (Agilent, Japan).

Table 2 shows the instrumental parameters for ICPMS. In the sample pretreatment (digestion procedure) a microwave oven (MARS xpress, CEM) was used.

2.4. Analytical Determinations. The mineral contents were analyzed by inductively coupled plasma mass spectrometry (ICP-MS) after microwave-assisted acid digestion. All glassware was cleaned with $\% 10(\mathrm{v} / \mathrm{v}) \mathrm{HNO}_{3}$ solution for one day and rinsed with ultrapure water. $1.0 \mathrm{~g}$ of each sample was digested with $4.0 \mathrm{~mL}$ of $65 \%$ (v/v) $\mathrm{HNO}_{3}$ and $0.5 \mathrm{~mL}$ of $35 \%(\mathrm{v} / \mathrm{v}) \mathrm{H}_{2} \mathrm{O}_{2}$ in PTFE vessels. The vessels were placed into microwave system (MARS 5, CEM). A blank digest was carried out in the same way. Digestion conditions for the microwave system applied were as follows: up to $120^{\circ} \mathrm{C}$ for $15 \mathrm{~min}$ and then constant for $10 \mathrm{~min}$; up to $160^{\circ} \mathrm{C}$ in $20 \mathrm{~min}$ and constant for $15 \mathrm{~min}$; finally, a cooling stage (30 min) was carried out to $22^{\circ} \mathrm{C}$ and diluted to $50 \mathrm{~mL}$ with deionized ultrapure water. This solution was finally used for elemental analysis, performed with an ICP-MS equipped with a concentric Nebulizer, a quartz torch with quartz injector tube, and cyclonic spray chamber. The concentrations of 13 elements ( $\mathrm{Na}, \mathrm{K}, \mathrm{Ca}, \mathrm{Mn}, \mathrm{Fe}, \mathrm{Cu}, \mathrm{Zn}, \mathrm{Se}, \mathrm{Al}, \mathrm{Cr}, \mathrm{Ni}, \mathrm{Cd}$, and $\mathrm{Pb}$ ) were determined in honey samples. The isotopes ${ }^{23} \mathrm{Na}^{+},{ }^{27} \mathrm{Al}^{+},{ }^{39} \mathrm{~K}^{+},{ }^{44} \mathrm{Ca}^{+},{ }^{52} \mathrm{Cr}^{+},{ }^{55} \mathrm{Mn}^{+},{ }^{56} \mathrm{Fe}^{+},{ }^{60} \mathrm{Ni}^{+},{ }^{78} \mathrm{Se}^{+}$, ${ }^{111} \mathrm{Cd}^{+},{ }^{208} \mathrm{~Pb}^{+},{ }^{66} \mathrm{Zn}^{+}$, and ${ }^{63} \mathrm{Cu}^{+}$were detected. All samples were analyzed in duplicate and each sample was measured in triplicate by ICP-MS detection.

2.5. Quality Control. Quality of this test procedure was assured by using certified reference material (NIST SRM 1515apple). Analyses of certified reference material allowed an assessment of accuracy and precision over a range of element concentrations. Certified values indicated that observed values correlated well with certified values as shown in Table 3. The accuracy of microwave digestion method was
TABLE 3: Minerals and heavy metals concentrations in certified reference material (NIST SRM 1515-apple).

\begin{tabular}{lccc}
\hline Element & Certified data $(\mathrm{ppm})$ & Our data $(\mathrm{ppm})$ & Recovery $(\%)$ \\
\hline $\mathrm{Na}$ & 10.0 & 9.94 & 99.4 \\
$\mathrm{Al}$ & 10.0 & 9.98 & 99.8 \\
$\mathrm{~K}$ & 10.0 & 9.94 & 99.4 \\
$\mathrm{Ca}$ & 10.0 & 10.1 & 101 \\
$\mathrm{Cr}$ & 10.0 & 9.93 & 99.3 \\
$\mathrm{Mn}$ & 10.0 & 9.96 & 99.6 \\
$\mathrm{Fe}$ & 10.0 & 10.1 & 101 \\
$\mathrm{Ni}$ & 10.0 & 9.94 & 99.4 \\
$\mathrm{Cu}$ & 10.0 & 10.0 & 100 \\
$\mathrm{Zn}$ & 10.0 & 9.98 & 99.8 \\
$\mathrm{Se}$ & 10.0 & 9.93 & 99.3 \\
$\mathrm{Cd}$ & 10.0 & 10.3 & 103 \\
$\mathrm{~Pb}$ & 10.0 & 10.2 & 102 \\
\hline
\end{tabular}

TABLE 4: Elemental concentrations of honey samples.

\begin{tabular}{lccc}
\hline Element & Minimum & Maximum & Mean \pm SD \\
\hline $\mathrm{Na}(\mathrm{ppm})$ & 0.48 & 13.1 & $2.92 \pm 3.36$ \\
$\mathrm{Al}(\mathrm{ppb})$ & $<1 \mathrm{ppb}$ & 960 & $69.7 \pm 141$ \\
$\mathrm{~K}(\mathrm{ppm})$ & 1.18 & 268 & $45.5 \pm 45.5$ \\
$\mathrm{Ca}(\mathrm{ppm})$ & $<1 \mathrm{ppb}$ & 4.5 & $1.67 \pm 0.82$ \\
$\mathrm{Cr}(\mathrm{ppb})$ & $<1 \mathrm{ppb}$ & $<1 \mathrm{ppb}$ & $<1 \mathrm{ppb}$ \\
$\mathrm{Mn}(\mathrm{ppb})$ & $<1 \mathrm{ppb}$ & 274 & $45.6 \pm 61.8$ \\
$\mathrm{Fe}(\mathrm{ppb})$ & $<1 \mathrm{ppb}$ & 7254.62 & $268 \pm 1036$ \\
$\mathrm{Ni}(\mathrm{ppb})$ & $<1 \mathrm{ppb}$ & $<1 \mathrm{ppb}$ & $<1 \mathrm{ppb}$ \\
$\mathrm{Cu}(\mathrm{ppb})$ & $<1 \mathrm{ppb}$ & 929 & $68.5 \pm 193$ \\
$\mathrm{Zn}(\mathrm{ppb})$ & $<1 \mathrm{ppb}$ & 237 & $49.9 \pm 49.7$ \\
$\mathrm{Se}(\mathrm{ppb})$ & $<1 \mathrm{ppb}$ & 65.9 & $54.1 \pm 11$ \\
$\mathrm{Cd}(\mathrm{ppb})$ & $<1 \mathrm{ppb}$ & $<1 \mathrm{ppb}$ & $<1 \mathrm{ppb}$ \\
$\mathrm{Pb}(\mathrm{ppb})$ & $<1 \mathrm{ppb}$ & $<1 \mathrm{ppb}$ & $<1 \mathrm{ppb}$ \\
\hline
\end{tabular}

checked by standard reference material. Three replicates were done for each sample of certified reference material and two measurements were performed for each digested sample.

\section{Results and Discussion}

Table 4 shows the concentration of 13 elements in 71 honey samples collected from the south and east region in Turkey. It is remarkable that the concentration of 13 elements summarizes wide variation and different honey samples. Among the analytes of the samples, the plenty of elements are $\mathrm{K}, \mathrm{Na}$, and Ca with average levels $45.5 \pm 45.5 \mathrm{ppm}, 2.92 \pm 3.36 \mathrm{ppm}$, and $1.67 \pm 0.82$ ppm, respectively.

$\mathrm{K}$ was identified as the first of the four major inadequate nutrients in the Dietary Guidelines for American 2010 Advisory Committee. K benefits relevant to organic anions related to $\mathrm{K}$ as it arises in foods such as honey. The $\mathrm{K}$ levels variate over a range within 1.18-268 ppm. In accordance with our data, higher amounts of $\mathrm{K}$ in honey samples were previously reported in Eastern Slovakia [8], Serpentin Area 


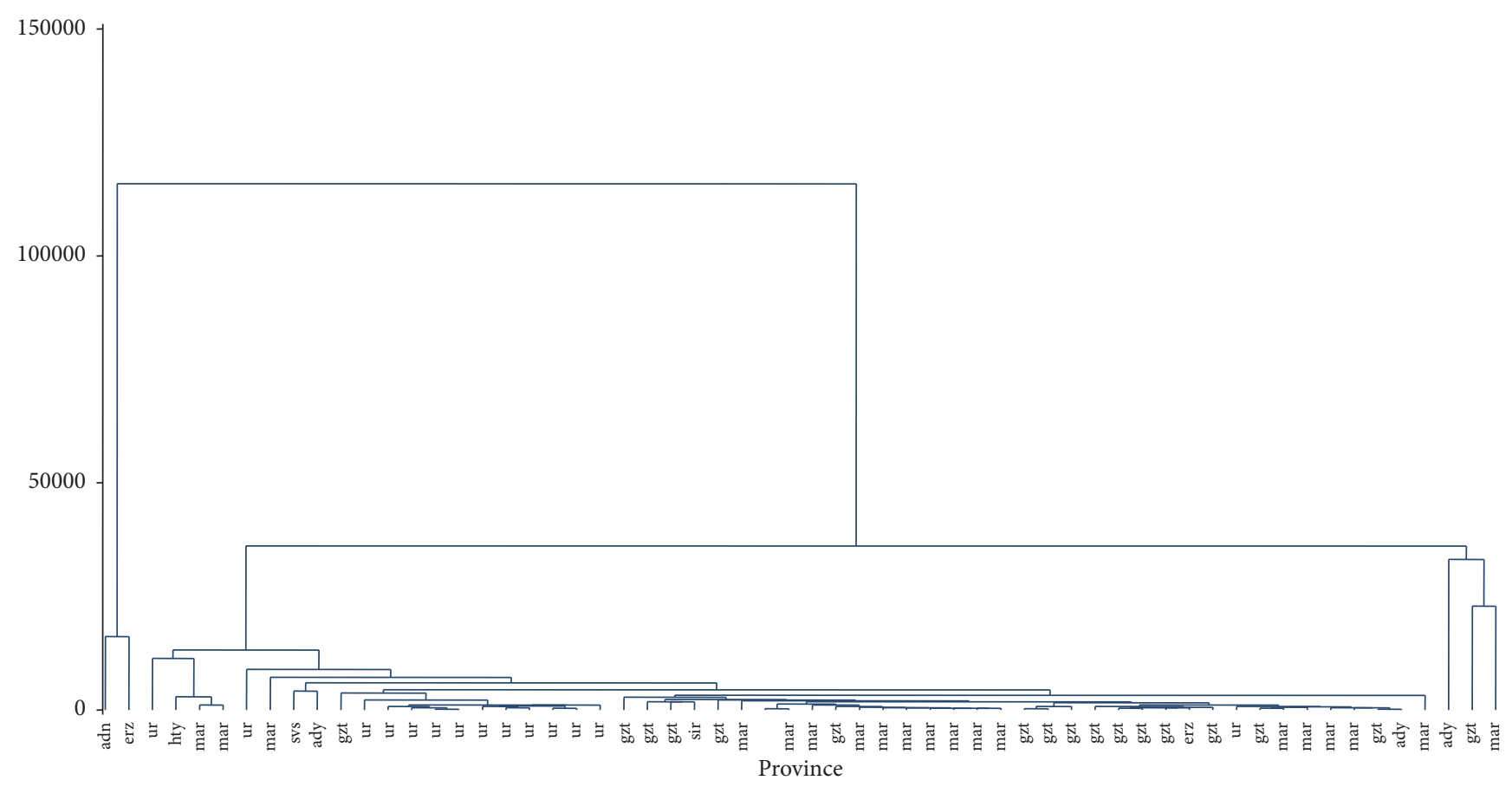

FIGURE 2: Hierarchical clustering results of honey samples (dendrogram).

in the Eastern Rhodopes Mt., Bulgaria [14], Argentine [5] and Hungarian honeys [10].

$\mathrm{Na}$ is an essential element for normal cell function, continuation of plasma volume, acid-base balance, and transmission of nerve impulses [17]. In the case of $\mathrm{Na}$, our honey samples $\mathrm{Na}$ content was lower $(2.92 \pm 3.36 \mathrm{ppm})$ than reported from the Argentine (with a mean level of $32.2 \pm$ $21.1 \mathrm{ppm}$ ) [5] and Eastern Slovakia monofloral honey samples $\mathrm{Na}(8.49 \pm 1.10 \mathrm{ppm})[8]$.

$\mathrm{Ca}$ is an essential nutrient for bone health to ensure the calcification of the bone [18]. In this study, Ca concentrations were found to be both the lowest $<1 \mathrm{ppm}$ (Hatay and Sanliurfa) and the highest $4.50 \mathrm{ppm}$ (Adana) in honey samples. The Ca levels have a range of $<1 \mathrm{ppb}-4.50 \mathrm{ppm}$ quite less than Eastern Slovakia [8] (20.3 $\pm 3.09 \mathrm{ppm})$ in monofloral honey samples and in Argentine honey samples [5] (6.92 \pm $4.35 \mathrm{ppm}$ ). Pisani et al. [19] sample's result is predominantly rich in Ca when we compare with our study.

$\mathrm{Al}$ is an abundant metal in Earth's crust. Bees are exposed to $\mathrm{Al}$ from many different sources when foraging for nectar externally. Our understanding of what constitutes "exposure" is likely prejudiced by a focus upon $\mathrm{Al}$ in the diet [20]. The highest $\mathrm{Al}$ concentration levels were $960 \mathrm{ppb}$ in the honey samples of Adana South Anatolia which is similar to the honey samples of Çankırı province $(1350 \mathrm{ppb})$. Differences between the samples may be contamination by the equipment of processing like Al containers or extractors used in the honey process [21]. The $\mathrm{Al}$ values of this study were lower when compared to other studies such as Anatolian honey samples of Yücel ve Sultanoğlu [22] (2540-11570 ppb). Di Bella et al. [23] and Czipa et al. [24] samples show a higher
$\mathrm{Al}$ concentration than our results. Southeast region of Turkey honey samples have lower mean $\mathrm{Al}$ concentrations when compared to other studies of the world [8,25] (Figure 2).

Se is a trace element that inherently exists in many foods such as honey. It is nutritionally essential for humans and is a component of more than twenty selenoproteins that play a critical part in reproduction, DNA synthesis, thyroid hormone metabolism, and protection from oxidative insult and infection [26]. The highest Se concentration was $65.9 \mathrm{ppb}$ in the sample of Hatay province while our data is similar to other Anatolian honey samples [11, 21]. For Se concentrations determined in this study, the mean concentration was very high compared to Argentine honey samples with the mean of $10 \mathrm{ppb}$ [5]. Se has an important role in antioxidant metabolism.

$\mathrm{Fe}$ is an essential element for the production of red blood cells. It has an ability to mediate electron transfer in the catalysis of enzymatic reactions which is also potentially toxic because it can catalyze the conversion of hydrogen peroxide into free radicals [27]. The mean level of Fe in honey samples is $269 \pm 1036 \mathrm{ppb}$ with the range of $<1 \mathrm{ppb}-7255 \mathrm{ppb}$. The previously detected Fe concentrations in honey samples from Southeastern Anatolia region were $2840-6660 \mathrm{ppb}$ [28]. The highest level of Fe concentrations in our study is higher than the honey samples of Kahramanmaraş city with the range of 40-1210 ppb [28]. We think that the reason for this is the plant flora that grows in that region and the highest level of Argentine's honey samples of Fe concentrations $4500 \mathrm{ppb}$ [5]. The Fe concentrations of the study were higher than the Romanian honeys (22.7 ppb); it can be caused by different soil and therefore vegetation diversity [1]. The Fe concentrations 
were a low range with honey samples from Canari Island (400-52510 ppb) [29]. Fe is an effective trace element whose deficiencies cause anemia.

$\mathrm{Zn}$ is generally considered to be an antioxidant and is found in nearly 100 specific enzymes [30]. It is "commonly the second most abundant transition metal in organisms" after $\mathrm{Fe}$ and it is the unique metal which arises in all enzyme tribes [31]. The lowest and the highest $\mathrm{Zn}$ concentrations were $<1 \mathrm{ppb}$ in honey samples from Şanlıurfa and Mardin and $237 \mathrm{ppb}$ in honey sample from Hatay, respectively. Average values for $\mathrm{Zn}$ were slightly lower than that analyst in the literature of other Anatolia honey samples with a mean level of 1100-12700 ppb [21] and Eastern Slovakia honey samples with a range of $159-1303 \mathrm{ppb}$ [8].

$\mathrm{Cu}$ is essential in the aerobic respiration of all eukaryotes [32]. The highest $\mathrm{Cu}$ content was $930 \mathrm{ppb}$ in Gaziantep (South Anatolia) honey, while the mean concentration of $\mathrm{Cu}$ of honey samples was $68.5 \pm 193 \mathrm{ppb}$. Conversely, the mean $\mathrm{Cu}$ concentration of our results was also high compared to other Anatolian honey samples from Kahramanmaraş province (10 ppb) [33] and low compared to Çankırı city (170 ppb) [11]. $\mathrm{Cu}$ levels were lower than other analysts for honey samples collected in Argentine [5].

The content of $\mathrm{Mn}$ in honey related to Genus Rubus accumulation which gives honey a typical smell $[8,34]$. The maximum and minimum Mn values observed $274 \mathrm{ppb}$ and $<1 \mathrm{ppb}$ in honey samples from Adana (South Anatolia) and Mardin (South East Anatolia), respectively. Mean values (45.6 $\pm 1.83 \mathrm{ppb}$ ) for Mn were slightly lower than those reported in the research literature for the Argentine honey samples (700 ppb) [5] whereas mean Mn levels of this study were higher than the Irish honey samples (40 ppb) [35].

The quite low concentrations of $\mathrm{Cr}, \mathrm{Ni}, \mathrm{Cd}$, and $\mathrm{Pb}$ $(<1 \mathrm{ppb})$ are attributed to the uncontaminated environment. In the south and east region of Turkey, the main sources of livelihood are animal breeding and agriculture so this area is not heavily industrialized. Mean $\mathrm{Cr}$ concentrations in Turkey were 2.4-37.9 ppb [21], 81.2-95.8 ppb [11], and 100-540 ppb [22]. $\mathrm{Cr}$ was more accumulated in honeydew of Slovakia honey with the range of $26.8-43.3 \mathrm{ppb}$ [8].

The Ni concentrations of our honey samples are similar to the Ni concentrations of Sakarya and İstanbul provinces (013-0.88 ppb) [6]. Honey samples of Hatay city in South Anatolia Ni concentrations are within $0.13-0.4 \mathrm{ppb}$ [22]. In Argentine honey samples the mean $\mathrm{Ni}$ concentration was $0.03 \mathrm{ppm}$. This mean data is higher than our Ni concentration [5]. Cd is an element whose source is soil passed to plants and nectar. Industrial pollution might contaminate soil or air [8]. The metals $\mathrm{Cd}$ and $\mathrm{Pb}$ are considered bioindicators for honey contamination [36]. Pb contamination generally correlates with air pollution by industry and exhaust gasses [8]. The samples of this study are collected from beekeepers who are located in mountain pasture far from the road and the factories so our data approved that.

The data of this study has shown that the honey which is produced in the east and south of Turkey does not pose a risk for heavy metals.

\section{Conclusions}

Seventy-one honey samples collected from south and east regions of Turkey were analyzed according to their metal contents. The concentrations of thirteen elements $(\mathrm{Na}, \mathrm{K}, \mathrm{Ca}, \mathrm{Mn}$, $\mathrm{Fe}, \mathrm{Cu}, \mathrm{Zn}, \mathrm{Se}, \mathrm{Al}, \mathrm{Cr}, \mathrm{Ni}, \mathrm{Cd}$, and $\mathrm{Pb}$ ) were analyzed by ICPMS.

The data suggested that honey samples of south and east regions of Turkey indicate the products' high quality because the concentrations of heavy metals were below the limit of detection (LOD). Also, botanical spectrum has an impact in apiculture. For more research of trace elements and heavy metal contents in honey, special attention might be demonstrated on the specific factor of honey production.

\section{Disclosure}

This paper was presented at the International Engineering, Science, and Education Conference (INESEC) which took place on December 1-3, 2016, in Diyarbakır/Turkey.

\section{Conflicts of Interest}

The authors declare that there are no conflicts of interest regarding the publication of this paper.

\section{References}

[1] M. Oroian, A. Prisacaru, E. C. Hretcanu, S. G. Stroe, A. Leahu, and A. Buculei, "Heavy metals profile in honey as a potential indicator of botanical and geographical origin," International Journal of Food Properties, vol. 19, no. 8, pp. 1825-1836, 2016.

[2] ftp://ftp.fao.org/docrep/fao/012/i0842e/i0842e10.pdf, 2016.

[3] Codex Alimentarius Commission, "Revised Codex Standard for Honey," Codex STAN 12-1981, Rev. 1 (1987), Rev. 2 ., 2001.

[4] L. Haouam, A. Tahar, H. Dailly, A. Lahrichi, A. Chaqroune, and C. Abdennour, "Physicochemical properties and major elements contents of Algerian honeys from semi-arid regions," Emirates Journal of Food and Agriculture, vol. 28, no. 2, pp. 107115, 2016.

[5] M. E. Conti, M. G. Finoia, L. Fontana, G. Mele, F. Botrè, and I. Iavicoli, "Characterization of Argentine honeys on the basis of their mineral content and some typical quality parameters," Chemistry Central Journal, vol. 8, no. 1, 2014.

[6] H. Altundag, S. Albayrak, M. S. Dundar, M. Tuzen, and M. Soylak, "Investigation of the influence of selected soil and plant properties from sakarya, turkey, on the bioavailability of trace elements by applying an in vitro digestion model," Biological Trace Element Research, vol. 168, no. 1, pp. 276-285, 2015.

[7] N. Samiullah, Cadmium Toxicity and Tolerance in Plants, Alfa Science International, 2006.

[8] J. Kováčik, J. Grúz, O. Biba, and J. Hedbavny, "Content of metals and metabolites in honey originated from the vicinity of industrial town Košice (eastern Slovakia)," Environmental Science and Pollution Research, vol. 23, no. 5, pp. 4531-4540, 2016.

[9] D. Citak, S. Silici, M. Tuzen, and M. Soylak, "Determination of toxic and essential elements in sunflower honey from Thrace Region, Turkey," International Journal of Food Science and Technology, vol. 47, no. 1, pp. 107-113, 2012. 
[10] M. Madejczyk and D. Baralkiewicz, "Characterization of Polish rape and honeydew honey according to their mineral contents using ICP-MS and F-AAS/AES," Analytica Chimica Acta, vol. 617, no. 1, pp. 11-17, 2008.

[11] S. Döker and M. Uslu, "Aerosol dilution technique for direct determination of ultra-trace levels of $\mathrm{Cr}, \mathrm{Mn}, \mathrm{Fe}, \mathrm{Co}, \mathrm{Ni}, \mathrm{Cu}$, and $\mathrm{Zn}$ in edible salt samples by collision/reaction cell inductively coupled plasma mass spectrometry (CRC-ICP-MS)," Food Analytical Methods, vol. 7, no. 3, pp. 683-689, 2014.

[12] A. B. Leme, S. R. Bianchi, R. L. Carneiro, and A. R. Nogueira, "Optimization of sample preparation in the determination of minerals and trace elements in honey by ICP-MS," Food Analytical Methods, vol. 7, no. 5, pp. 1009-1015, 2014.

[13] M. Biesaga and K. Pyrzyńska, "Stability of bioactive polyphenols from honey during different extraction methods," Food Chemistry, vol. 136, no. 1, pp. 46-54, 2013.

[14] J. Atanassova, D. Pavlova, M. Lazarova, and L. Yurukova, "Characteristics of honey from serpentine area in the Eastern Rhodopes Mt., Bulgaria," Biological Trace Element Research, vol. 173, no. 1, pp. 247-258, 2016.

[15] http://www.fas.usda.gov, 2016.

[16] http://www.tuik.gov.tr/HbGetir.do?id=21822\&amp;tb_id=10, 2016.

[17] http://apps.who.int/iris/bitstream/10665/77985/1/9789241504836_ eng.pdf, 2016.

[18] L. D. Tuyen, V. T. T. Hien, P. T. Binh, and S. Yamamoto, "Calcium and vitamin D deficiency in vietnamese: recommendations for an intervention strategy," Journal of Nutritional Science and Vitaminology, vol. 62, no. 1, pp. 1-5, 2016.

[19] A. Pisani, G. Protano, and F. Riccobono, "Minor and trace elements in different honey types produced in Siena County (Italy)," Food Chemistry, vol. 107, no. 4, pp. 1553-1560, 2008.

[20] C. Exley, "Human exposure to aluminium," Environmental Sciences: Processes and Impacts, vol. 15, no. 10, pp. 1807-1816, 2013.

[21] M. Tuzen, S. Silici, D. Mendil, and M. Soylak, "Trace element levels in honeys from different regions of Turkey," Food Chemistry, vol. 103, no. 2, pp. 325-330, 2007.

[22] Y. Yücel and P. Sultanoğlu, "Characterization of hatay honeys according to their multi-element analysis using ICP-OES combined with chemometrics," Food Chemistry, vol. 140, no. 1, pp. 231-237, 2013.

[23] G. Di Bella, V. L. Turco, A. G. Potortì, G. D. Bua, M. R. Fede, and G. Dugo, "Geographical discrimination of italian honey by multi-element analysis with a chemometric approach," Journal of Food Composition and Analysis, vol. 44, pp. 25-35, 2015.

[24] N. Czipa, D. Andrási, and B. Kovács, "Determination of essential and toxic elements in hungarian honeys," Food Chemistry, vol. 175, pp. 536-542, 2015.

[25] B. L. Batista, L. R. S. da Silva, B. A. Rocha et al., "Multi-element determination in brazilian honey samples by inductively coupled plasma mass spectrometry and estimation of geographic origin with data mining techniques," Food Research International, vol. 49, no. 1, pp. 209-215, 2012.

[26] https://ods.od.nih.gov/actsheets/Selenium-HealthProfessional/, 2016.

[27] N. C. Andrews, "Disorders of iron metabolism," New England Journal of Medicine, vol. 341, no. 26, pp. 1986-1995, 1999.

[28] E. Yarsan, F. Karacal, I. G. Ibrahim, B. Dikmen, A. Koksal, and Y. K. Das, "Contents of some metals in honeys from different regions in Turkey," Bulletin of Environmental Contamination and Toxicology, vol. 79, no. 3, pp. 255-258, 2007.
[29] O. M. Hernández, J. M. G. Fraga, A. I. Jiménez, F. Jiménez, and J. J. Arias, "Characterization of honey from the Canary Islands: determination of the mineral content by atomic absorption spectrophotometry," Food Chemistry, vol. 93, no. 3, pp. 449-458, 2005.

[30] NRC, Nutrient Requirements of Beef Cattle, National Academies Press, Washington, DC, USA, 7th edition, 2000.

[31] M. R. Broadley, P. J. White, J. P. Hammond, I. Zelko, and A. Lux, "Zinc in plants: tansley review," New Phytologist, vol. 173, no. 4, pp. 677-702, 2007.

[32] J. T. Rubino and K. J. Franz, "Coordination chemistry of copper proteins: how nature handles a toxic cargo for essential function," Journal of Inorganic Biochemistry, vol. 107, no. 1, pp. 129143, 2012.

[33] F. Erbilir and Ö. Erdoĝrul, "Determination of heavy metals in honey in Kahramanmaraş City, Turkey," Environmental Monitoring and Assessment, vol. 109, no. 1-3, pp. 181-187, 2005.

[34] E. Kula, P. Hrdlička, J. Hedbávný, and P. Švec, "Various content of manganese in selected forest tree species and plants in the undergrowth," Beskydy, vol. 5, no. 1, pp. 19-22, 2013.

[35] G. Downey, K. Hussey, J. D. Kelly, T. F. Walshe, and P. G. Martin, "Preliminary contribution to the characterisation of artisanal honey produced on the island of Ireland by palynological and physico-chemical data," Food Chemistry, vol. 91, no. 2, pp. 347354, 2005.

[36] S. Bogdanov, M. Haldimann, W. Luginbühl, and P. Gallmann, "Minerals in honey: environmental, geographical and botanical aspects," Journal of Apicultural Research, vol. 46, no. 4, pp. 269275, 2007. 

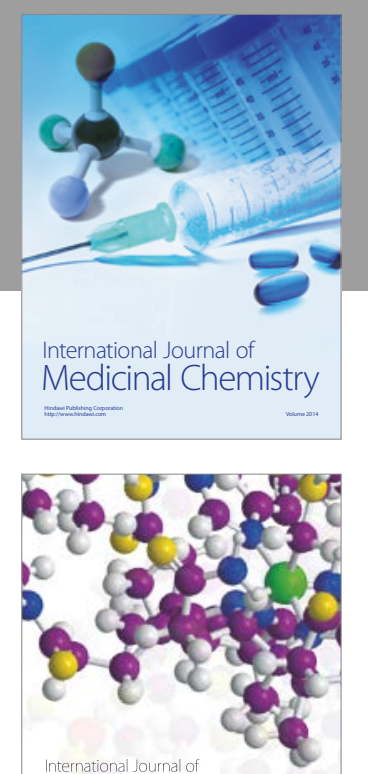

Carbohydrate Chemistry

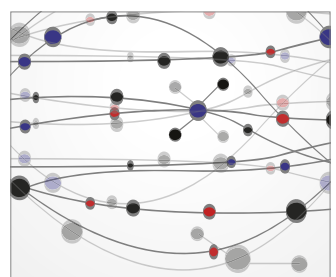

The Scientific World Journal
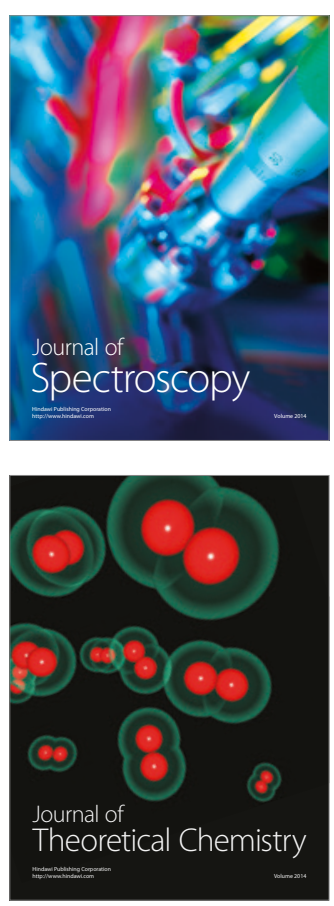
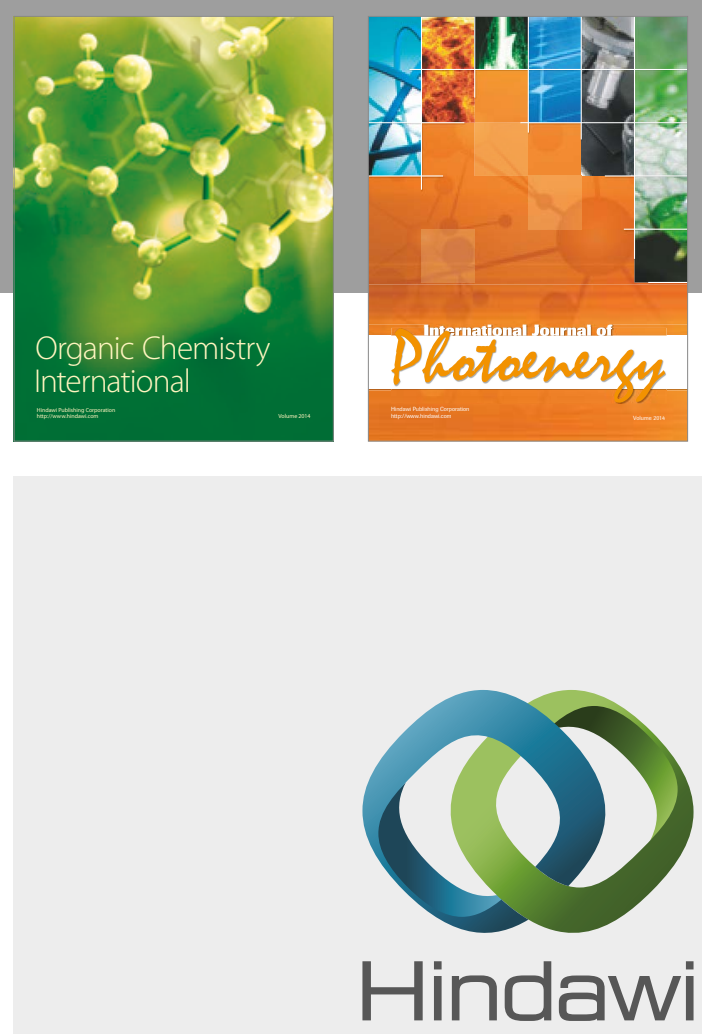

Submit your manuscripts at

https://www.hindawi.com

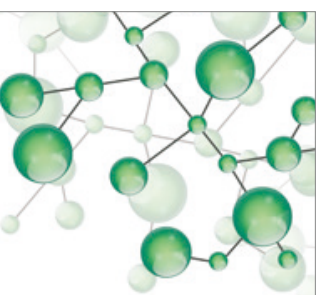

International Journal of

Inorganic Chemistry

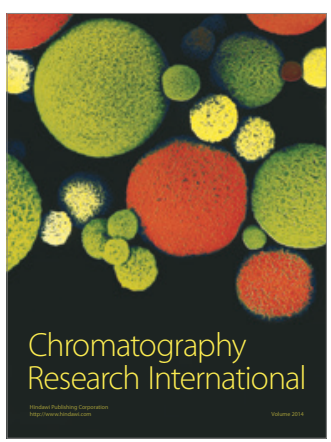

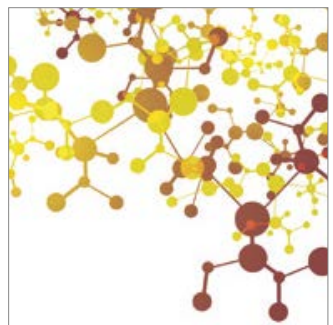

Applied Chemistry
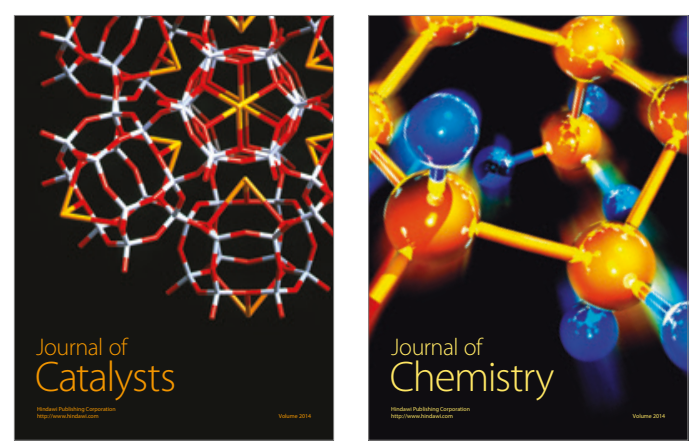
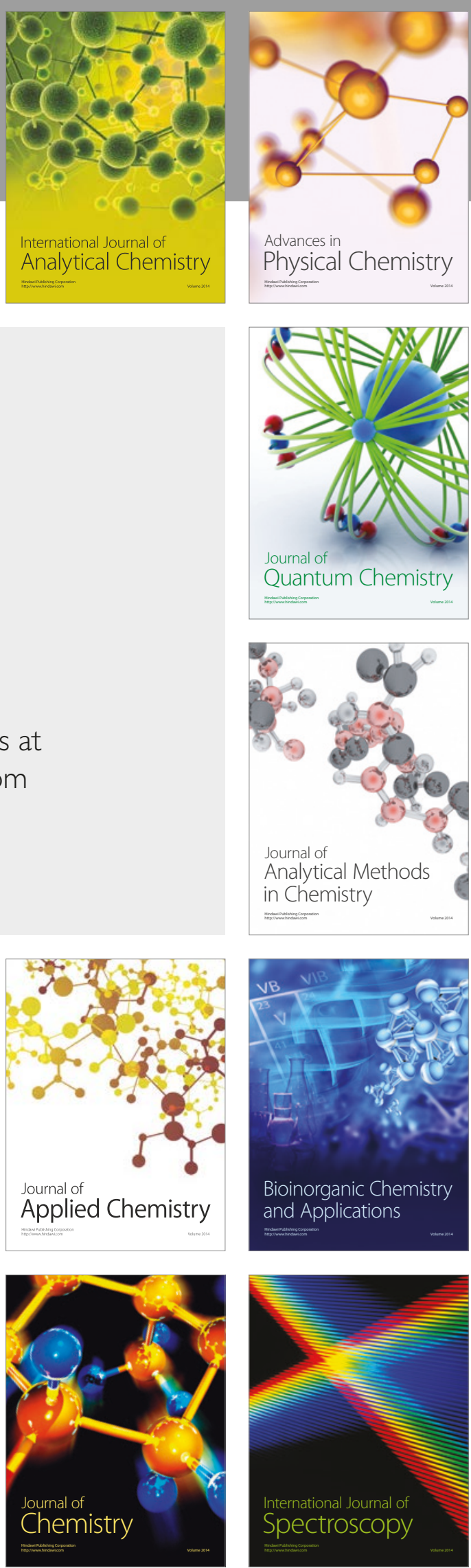